\title{
プラズマ照射による金属表面の濡れ性変化と液滴蒸発 Change in Wettability by Plasma Irradiation and Evaporation of Water Drop
}

\author{
○正 日高 澄具（九州大） 学 山本 弘志（九州大院） 学 山下 秋満（九州大院） \\ 正 高田 保之（九州大） 正 伊藤 猛宏（東要大学）
}

Sumitomo HIDAKA, Hiroshi YAMAMOTO, Akimitu YAMASHITA, Yasuyuki TAKATA and Takehiro ITO

Department of Mechanical Engineering Science, Kyushu University, 6-10-1 Hakozaki, Higashi-ku, Fukuoka

Graduate School of Integrated Science and Art, University of East Asia, 2-1 Ichinomiyagakuen-cho, Shimonoseki

Experimental study has been performed on evaporation of water droplet on a copper surface. This surface is exposed by the Plasma irradiation to increase the wettability. We measured the relation between the Plasma irradiation and contact angle first, and then the evaporation time, the wetting limit temperature and Leidenfrost point of droplet, increasing the surface temperature. The effect of Plasma irradiation on evaporation curve has been examined. It is found that the evaporation time decreases, and wetting limit temperature and Leidenfrost point increases as the contact angle decreaces.

Key Words: Plasma, Contact angle, Droplet Evaporation, Leidenfrost Point

\section{1. 粕夆}

物質の表面にプラズマを照射すると，その表面は濡れや すくなる．プラズマ粒子が固体表面上に形成された気体吸 着層を除去することで,活性度の高い酸化層があらわれる。 この洗浄・活性効果が，表面を改質し濡れ性を高める。プ ラズマ処理は，工業的には樹脂部品等の濡れ性が低い物質 への接着前処理や印刷前処理などに利用されている，樹脂 等へのプラズマ処理の研究は多くなされているが, 金属に 関してのものは少ない。

著者らは，酸化チタンをスパッタリングした銅伝熱面を 用い，紫外線照射により接触角を変化させた場合の伝熱実 験を行った[1]，同様にプラズマ照射による接触角の変化か ら伀熱促進を図り，加熱面上で単一液滴を蒸発させる実験 を行った[2]。この実験により, 接触角が蒸発熱伝達に及ぼ す影響をより明確にできるものと考えている.

本研究では, プラズマ照射時間による接触角の変化, プ ラズマ照射した表面の接触角の時間的変化などの基礎デー 夕を得た後, 高温域までの液滴蒸発実験を行い, 接触角之 濡れ限界温度, Leidenfrost 点の関係について比較検討した。

\section{2. 实唤装晴と方法}

本実験では，表面を研磨したのみの通常面と，プラズマ 照射面についてそれぞれ液滴等価直径が 2.16, 2.40, 2.66, $2.93 \mathrm{~mm}$ の 4 通りの実験を行った.

伝熱面は， $\phi 30 \mathrm{~mm}$ の銅円柱の端面が平らなものと, Leidenfrost 点近傍のデータを得るため, その中心が $3 \mathrm{~mm}$ 球面状に䇠んだものの 2 種類を用意した。伝熱面温度は銅 円柱下部に巻きつけたヒーターにより調節する。伝熱面温 度は伝熱面から $10 ， 15 ， 20 \mathrm{~mm}$ の銅円柱中心部に取りつ けた熱電対により得た

液滴は伀熱面上方に配した注射器の内筒をマイクロメー タで徐々に押し自由落下させた．伝熱面と注射針先端の距 離は $10 \mathrm{~mm}$ とした。

蒸発時間は，液滴が落下した瞬間から完全に蒸発するま での時間を目視によりストップウォッチで計測した.また， 蒸発の様相を高速度力メラで撮影しており，その映像から 濡れ限界温度，Leidenfrost 点を判定した．測定は，10 K 間 隔で行い，Leidenfrost 点近傍では温度間隔を細かくして測 定した。濡れ限界温度, Leidenfrost 点は次のよう区別して いる。濡れ限界温度近傍では，伝熱面に落下した液滴は一
旦伝熱面上で広がり薄い液膜を形成した後, 激しい蒸発に 伴い液膜上の液体が上方に飛ばされ小さな液滴を形成する. この液滴が再び伝熱面に衝突した時，蒸発する場合を濡れ 限界温度以下とする。 Leidenfrost 点より高温側では，落下 した液滴は伝熱面上で広がり短時間の固液接触後, 液滴は 分裂せず液滴下部に蒸気膜が形成される。

\section{3. 实臨结果と考事}

はじめに, プラズマを照射した表面の基礎データを図 1 , 2 に示す.

図 1 は, エメリー紙\#600,\#1000,\#1500,\#2000, および ミラ一仕上げの 5 種類の表面におけるプラズマ照射時間と 接触角の関係を表す。接触角はプラズマ照射停止後直ちに 測定した．照射時間が短い場合は，表面が滑らかなほど接 触角が大きいが，照射時間が 100 秒を超えると粗さによる 接触角の差が小さくなる.

図 2 は，同じ 5 種類の表面にそれぞれ 40 秒，60 秒，120 秒プラズマを照射した後, 時間の経過とともに接触角が上 昇する様子を示したものである．照射時間 40 秒， 60 秒， 120 秒の順に接触角が小さくなっている．線で結んだ照射 時間 120 秒のデー夕は, 比較的接触角が小さいが, 特に\#600, 経過時間 300 秒以内では接触角が, 約 $10^{\circ}$ と安定している. いずれの場合も，プラズマを照射する直前に表面を仕上げ ている.

液滴蒸発実験では，同一の表面にプラズマ照射を行うた め, プラズマ照射の繰り返しによる接触角の再現性を確認 した．最初に一度だけエメリ一紙\#600で研磨した伝熱面を 約 $60{ }^{\circ} \mathrm{C}$ に加熱し, 10 分毎に 120 秒間のプラズマ照射と液 滴径 $2.16 \mathrm{~mm}$ の落下を繰り返し行い接触角を測定した。 そ の結果, 銅は約 $10^{\circ}$ で接触角が安定することが確認された.

図 3,はエメリ一紙 6000 で研磿した伝熱面上に 4 種類の 大きさの液滴を落下させ，その蒸発時間を測定したもので ある，伝熱面温度が低い時は，液滴径が大きいほど蒸発時 間が長く，高温になるとその差はなくなる．この時の濡れ 限界温度は，液滴の大きさによらず約 $130^{\circ} \mathrm{C}$ であり Leidenfrost 点は約 $132^{\circ} \mathrm{C}$ であった。

図中の○印は，参考のために以前の実験で得られたデー 夕を示した。これは， $\phi 17 \mathrm{~mm}$ の銅円柱端面中心を $0.3 \mathrm{~mm}$ 涳ませ， mirror 仕上げをした伝熱面より得られた。濡れ限 界温度より高温側では，表面粗さが蒸発時間に大きく影響 
する事がわかる．伝熱面表面が粗い場合，液滴下部に均一 の厚さの蒸気膜ができにくく，局所的に蒸気膜が破断され 固液接触が起こる.そのため、現象は不安定である.

図 4 は, 図 3 と同様の手順で実験を行ったが, 液滴を落 下させる直前にプラズマを 120 秒間照射した．図 3 と比べ ると低温域では, 液滴径が大きいほど蒸発時間は長いが, 蒸発時間の差は小さくなり，蒸発時間が減少している。濡 れ限界温度は, 約 $150^{\circ} \mathrm{C}$ であり, Leidenfrost 点は約 $156^{\circ} \mathrm{C}$ であったフプラズマを照射しない伝熱面に比べ，その間の 遷移域に大きな差が見られる。図 3 , 図 4 いずれの場合も 拝れ限界温度より高温側では, 液滴が伝熱面上から飛び出 すことを防ぐため, 伝熱面中心を球面状に $3 \mathrm{~mm}$ 窪ませた ものを使用した。

図 5 , 図 6 は, 濡れ限界温度, Leidenfrost 点近傍を拡大 表示した．プラズマを照射した場合は，濡れ限界温度より 高温側でも蒸発時間が減少していることがわかる

\section{4. 结霅}

本報では，プラズマ照射した伝熱面の接触角の安定性の確 認と液滴蒸発実験を行い，以下のことが確認された。

1）＃600の表面に 120 秒プラズマ照射することで安定し た低い接触角が得られる.

2) 濡れ限界温度, Leidenfrost 点は, 接触角が小さい方が 高くなる.

3）プラズマを照射すると, 低温域では蒸発時間が减少し, 濡れ限界温度より高温側でも蒸発時間が減少する。

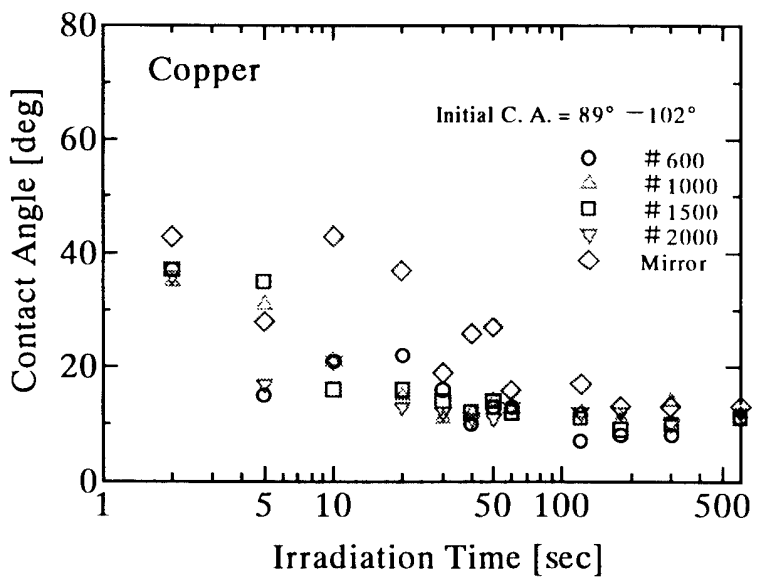

Fig.1 Contact angle and surface condition

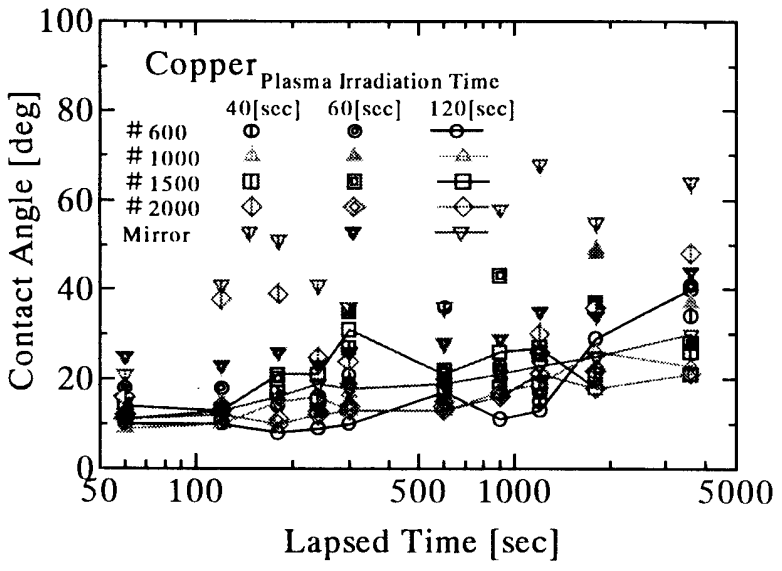

Fig.2 Effect of lapsed time on contact angle

\section{5. 考文献}

1. 高田保之ら, 第 38 回日本伝熱シンポジウム講演論文集, G123，2001

2. 日高澄具ら,第 39 回日本伝熱シンポジウム講演論文集, E211，2002

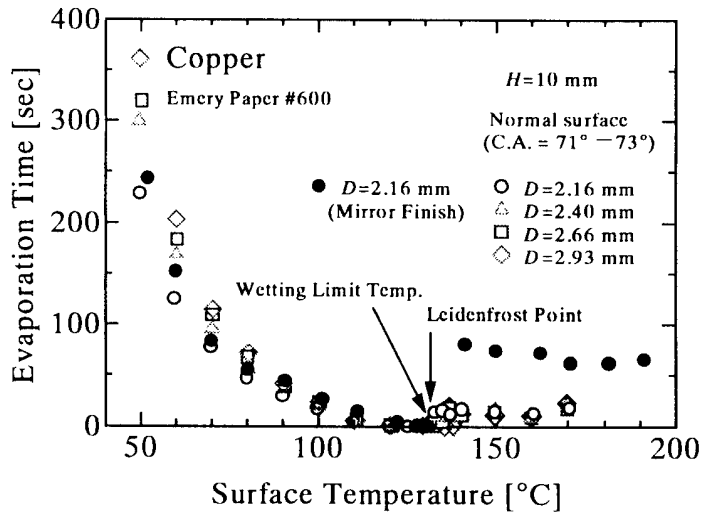

Fig.3 Evaporation curve for C.A. $72^{\circ}$

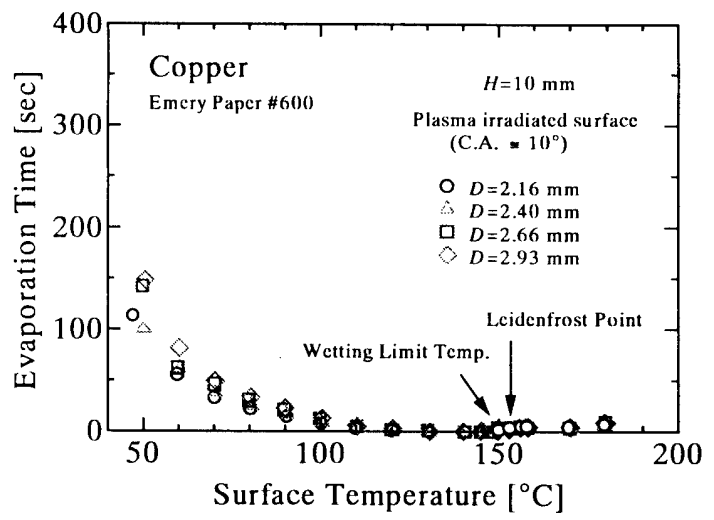

Fig.4 Evaporation curve for C.A. $10^{\circ}$

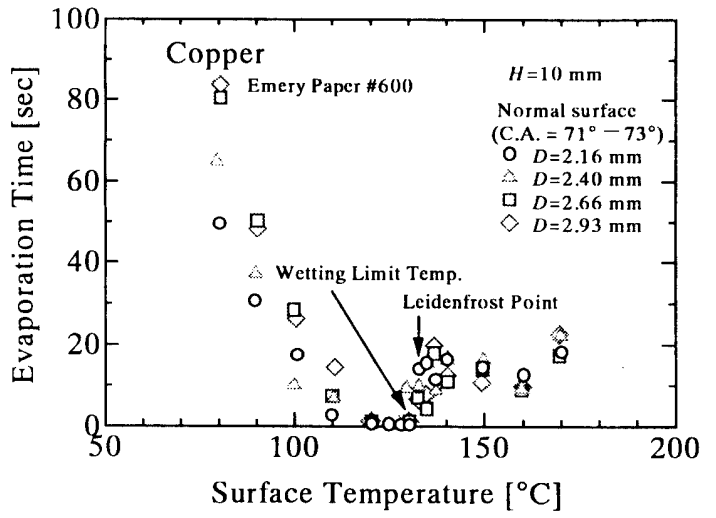

Fig. 5 Evaporation curve for C.A. $72^{\circ}$

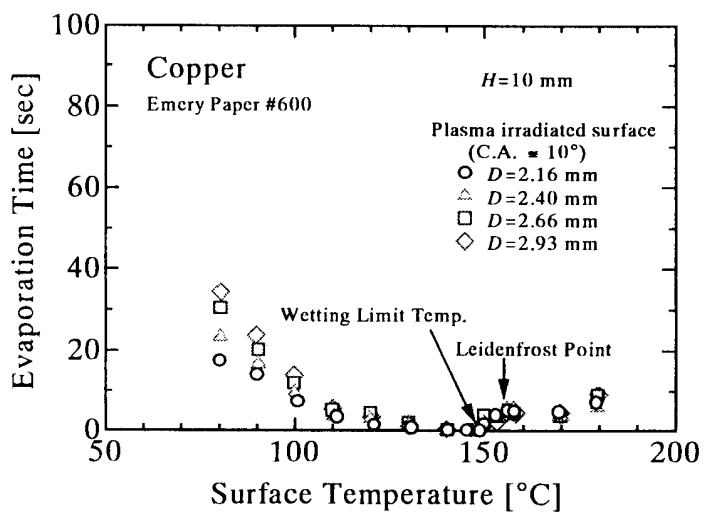

Fig.6 Evaporation curve for C.A. $10^{\circ}$ 